\title{
Aerobic exercise attenuates the effects of ovariectomy and sedentarism on body composition and food intake in female rats
}

\section{Exercício aeróbico atenua os efeitos}

da ovariectomia e do sedentarismo

na composição corporal e no

consumo alimentar em ratas

Frederico Souzalima Caldoncelli FRANCO ${ }^{1}$ iD 0000-0002-7880-4258

Antônio José NATALI² (iD) 0000-0002-4927-4024

Neuza Maria Brunoro COSTA 3 (iD) 0000-0002-4967-9937

A B S TR A C T

\section{Objective}

To evaluate the impact of low to moderate aerobic exercise and ovariectomy on body composition and food consumption in female rats.

\section{Methods}

Forty adult Wistar female rats (age: 23 weeks; body weight: $275.2 \pm 3.6 \mathrm{~g}$; mean \pm SEM) were divided into 4 groups $(n=10)$ : laparotomy-sedentary; laparotomy-exercised; ovariectomy-sedentary; and ovariectomy-exercised. The exercised

\footnotetext{
1 Instituto Federal de Educação, Ciência e Tecnologia do Sudeste de Minas Gerais, Departamento Acadêmico de Educação, Núcleo Educação Física. Campus Rio Pomba, Av. Dr. José Neves, n. 500, Centro, 36180-000, Rio Pomba, MG, Brasil. Correspondece to: FSC FRANCO. E-mail: <frederico.franco@ifsudestemg.edu.br>.

2 Universidade Federal de Viçosa, Departamento de Educação Física, Programa de Pós-Graduação em Educação Física. Viçosa, MG, Brasil.

3 Universidade Federal do Espírito Santo, Departamento de Farmácia e Nutrição, Centro de Ciências Exatas, Naturais e da Saúde. Alegre, ES, Brasil.

Article based on the dissertation by FSC FRANCO, entitled "Effects of ovariectomy, caffeine intake and aerobic exercise associated with adequacy or not of dietary calcium intake in body composition, bone tissue and calcium balance in rats". Universidade Federal de Viçosa; 2009.
}

\section{How to cite this article}

Franco FSC, Natali AJ, Costa NMB. Aerobic exercise attenuates the effects of ovariectomy and sedentarism on body composition and food intake in female rats. Rev Nutr. 2021;34:e200263. https://doi.org/10.1590/1678-9865202134e200263 
groups were submitted to a treadmill running program (16m/min; 30min/day, 5 days/week), for 8 weeks. Body weight and food consumption were monitored during the experiment. Visceral fat and carcass water, protein, ash, fat and carbohydrate fractions were analyzed. Two-way ANOVA plus the Tukey's post hoc test was used for comparisons and $p<0.05$ was considered significant.

\section{Results}

The ovariectomized (ovariectomy-sedentary+ovariectomy-exercised) and sedentary (laparotomy-sedentary+ovariectomysedentary) animals showed higher $(p<0.05)$ weight gain, food consumption, food efficiency ratio and weight gain/body weight ratio than laparotomy animals (laparotomy-sedentary+laparotomy-exercised) and exercised (exercised laparotomy+exercised ovariectomy), respectively. The ovariectomized and sedentary animals showed higher ( $p<0.05$ ) carcass weight, fat percentage and visceral fat than laparotomy and exercised rats, respectively.

\section{Conclusion}

Ovariectomy and physical inactivity increase obesogenic indicators, whereas regular aerobic exercise of low to moderate intensity attenuates these unfavorable effects in female rats.

Keywords: Food consumption. Intra-Abdominal fat. Physical exercise. Weight gain.

\section{RE S U M O}

\section{Objetivo}

Avaliar o impacto do exercício aeróbico de intensidade baixa a moderada e da ovariectomia na composição corporal e no consumo alimentar em ratas.

\section{Métodos}

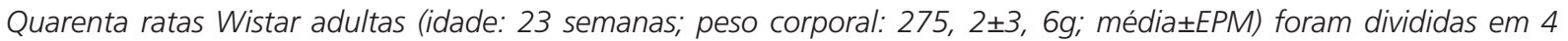
grupos ( $n=10)$ : laparotomia-sedentária, laparotomia-exercitada, ovariectomia-sedentária e ovariectomia-exercitada. Os grupos laparotomia-exercitada e ovariectomia-exercitada foram submetidos a um programa de corrida em esteira (16m/ mim; 30min/dia, 5 dias/semana) durante 8 semanas. Foram monitorados o peso corporal e o consumo alimentar das ratas durante o experimento. Analisaram-se as frações de água, proteínas, cinzas, gordura e carboidrato da carcaça, bem como a gordura visceral. Empregou-se ANOVA Two-Way, seguida do teste post hoc de Tukey para as análises estatísticas. Adotou-se o nível de significância de $p<0,05$.

\section{Resultados}

As ratas ovariectomizadas (ovariectomia-sedentária+ovariectomia-exercitada) e sedentárias (laparotomia-sedentária+ ovariectomia-sedentária) exibiram maior $(p<0,05)$ ganho de peso, consumo alimentar, coeficiente de eficácia alimentar e taxa de ganho de peso/peso corporal do que as ratas laparotomizadas (laparotomia-sedentária+laparotomia-exercitada) e exercitadas (laparotomia-exercitada+ovariectomia-exercitada), respectivamente. A carcaça das ratas ovariectomizadas e sedentárias apresentaram maior $(p<0,05)$ peso, percentual de gordura e gordura visceral do que as ratas laparotomizadas e exercitadas, respectivamente.

\section{Conclusão}

A ovariectomia e o sedentarismo elevam indicadores obesogênicos, enquanto que o exercício aeróbico regular de intensidade baixa a moderada atenua esses efeitos desfavoráveis em ratas.

Palavras-chave: Consumo alimentar. Gordura intra-abdominal, Exercício físico, Ganho de peso.

\section{INTROD U CTION}

Obesity is growing worldwide, being one of the main public health problems, especially in postmenopausal women [1-4]. Menopause is a natural aging process in women that promotes metabolic and body changes by increasing weight and body fat, which may increase the risk of cardiovascular diseases, obesity, diabetes, hypertension and cancer [2-8].

Studies with humans and animals have shown that postmenopausal obesity may occur due to hormonal dysfunction, greater physical inactivity and increased food intake, although some authors have reported an inconsistent impact of the ovarian function loss on food consumption [6,7,9-12]. 
Although estrogen is known to suppress body fat and to protect against certain chronic diseases, some authors have not observed an effect of ovariectomy surgery on body weight $[7,12,13]$. Such inconsistencies require further studies on the absence of estrogen caused by ovariectomy on body composition, especially on the accumulation of muscle fat.

Aerobic exercises promote adaptations which are beneficial to the cardiovascular system by increasing energy expenditure and inhibiting weight gain, being a strategy for obesity control [2,4,7,9,14-16]. However, postmenopausal and elderly women usually participate in aerobic exercises programs of very low intensity such as walking, which promote minor effects on body composition [14,17].

Studies report that rats running on the treadmill for 60 minutes at 10 to $12 \mathrm{~m} / \mathrm{min}$ did not experience benefits on body composition, but at 17.5 and $18 \mathrm{~m} / \mathrm{min}$ running showed an increase in aerobic energy markers $[7,14,17,18]$. In contrast, the $16 \mathrm{~m} / \mathrm{min}$ run at an intensity of $65 \%$ promoted more aerobic benefits [14]. However, in the study of Miyatake et al. [13] no weight change in mice was observed. This information inconsistency shows the need for further studies on the impact of running intensity on body composition.

Exercises have shown to be effective against weight gain and the deleterious effects of postmenopausal aging $[6,8,12,19]$. However, the low to moderate $16 \mathrm{~m} / \mathrm{min}$ aerobic running intensity on body composition is not yet known, as well as its effect with the deprivation of the ovarian hormone. Thus, the objective of this study was to assess the impact of low to moderate aerobic exercise and ovariectomy on body composition and food consumption in Wistar rats.

\section{METHODS}

The study was carried out with 40 adult Wistar female rats (weight: 275.2 $\pm 3.6 \mathrm{~g}$; mean \pm MSE). In the $23^{\text {rd }}$ week of life, the rats were submitted to Ovariectomy (OVX) or laparotomy (Sham) surgery. The animals were previously anesthetized with intramuscular ketamine $(70 \mathrm{mg} / \mathrm{kg}$ ) and intramuscular xylazine $(8 \mathrm{mg} / \mathrm{kg})$, receiving subcutaneous administration of the anti-inflammatory substance Ketofen: $2 \mathrm{mg} / \mathrm{kg} / 3 \mathrm{~d}$ and antibiotic (sodium ampicillin: $30 \mathrm{mg} / \mathrm{kg}$ ) $\mathrm{kg} / 5 \mathrm{~d}$ ) $[20,21]$. After 3 weeks of recovery, the animals were allocated into 4 groups $(n=10)$, in a $2 \times 2$ factorial design: SHAM Sedentary (SS), SHAM Exercised (SE), OVX Sedentary (OS) e OVX Exercised (OE).

The animals were housed in individual cages for 8 weeks, kept in an environment at a temperature of $22 \pm 2^{\circ} \mathrm{C}$, relative humidity of about $60 \%$, and a photoperiod of 12 hours, in addition to receiving daily 18 to $20 \mathrm{~g}$ of AIN-93M diet and deionized water ad libitum [22]. The animals were obtained from the vivarium of the Centro de Ciências Biológicas e da Saúde da Universidade Federal de Viçosa, MG (Brazil), and the experimental procedures were approved by the Ethics Committee of the Veterinary Department of UFV MG (Opinion No. 80/2007).

After 2 weeks of recovery from surgery, all rats (20 SHAM and 20 OVX) underwent a process of adaptation to a running exercise on a treadmill $(5-7 \mathrm{~m} / \mathrm{min}, 8 \mathrm{~min} /$ day) for one week (Table 1). The 10 rats from each surgery (SHAM and OVX), which were better adapted to the exercise, started to form the ES and EO groups, that were submitted to a progressive program of aerobic workout on a treadmill with no incline (adapted from Ferreira et al. [17]); the rats underwent 5 sessions/week workout, for 8 weeks. These animals exercised at progressive speed and duration, and from the $3^{\text {rd }}$ to the $8^{\text {th }}$ week the speed was set at $16 \mathrm{~m} / \mathrm{min}$ and the duration was $30 \mathrm{~min} /$ day. The other SHAM and OVX rats became part of the SS and SO groups and remained in their cages during the experimental period.

In the last experimental week, the blood lactate of the exercised animals (groups SE and OE) during a training session was determined. Five animals were evaluated per group, chosen at random. 
Table 1 - Exercise program. Viçosa (MG), Brazil, 2009

\begin{tabular}{|c|c|c|c|c|}
\hline Variables & Day of the week & Velocity (m/mim) & Time $(\min )$ & Running distance $(\mathrm{m})$ \\
\hline Adaptation (1 week) & Monday to Friday & 5 to 7 & 8 & 50 \\
\hline \multirow[t]{5}{*}{$1^{\text {st }}$ week } & Monday & 10 & 10 & 100 \\
\hline & Tuesday & 10 & 15 & 150 \\
\hline & Wednesday & 10 & 20 & 200 \\
\hline & Thursday & 10 & 25 & 250 \\
\hline & Friday & 10 & 30 & 300 \\
\hline \multirow[t]{4}{*}{$2^{\text {nd }}$ week } & Monday & 10 & 30 & 300 \\
\hline & Tuesday & 12 & 30 & 360 \\
\hline & Wednesday & 14 & 30 & 420 \\
\hline & Thursday and Friday & 16 & 30 & 480 \\
\hline $3^{\text {rd }}$ to $8^{\text {th }}$ week & Monday to Friday & 16 & 30 & 480 \\
\hline Performance test & & 16 & 30 & 480 \\
\hline
\end{tabular}

The measurements were carried out at 3 points in time: at rest and after 15 minutes and 30 minutes running [23]. Blood was collected from the animals' tail end to dose the lactate concentration the Accusport BM-Lactate equipment (Roche ${ }^{\circledR}$, Germany) was used [14].

At the end of the $8^{\text {th }}$ week, all the animals in each group were euthanized; visceral fat was removed and weighed. The empty carcass (muscles and bones) was separated and stored in a freezer at $-20^{\circ} \mathrm{C}$ to further determine the fractions: water, fat, proteins and ashes. The water content rate was evaluated using the gravimetric method by water evaporation in an oven (Fanem, Brazil) at $105^{\circ} \mathrm{C}$ for 24 hours. The fat percentage was determined by the gravimetric method in a Soxhlet apparatus using ethyl ether as solvent in an 8 hours/extraction. The percentage of protein was calculated in triplicate by the indirect method of nitrogen determination (Protein $(g)=$ nitrogen $(g) \times 6.25$ ) by the Kjeldahl method. The percentage of ash was determined by incineration at $600^{\circ} \mathrm{C}$ for 6 hours. The percentage of carbohydrates was calculated by the equation, $100 \%$ - (\% of water, protein, ash and fat). The analyses were conducted according to the official A.O.A.C. methods [24].

The body weight of all animals in each group and the dietary intake of 5 animals in each group, chosen at random, were monitored weekly using a digital electronic scale (Mars, Brazil). Weight gain was determined calculating the weight difference between sacrifice time point and the first week of life. The Food Efficiency Ratio (FER\%) was determined by the equation [FER\%=(body weight gain/diet consumption) x100]. The Weight Gain Rate by Body Weight was determined by WGR=(body weight gain/final weight) $\mathrm{x} 100$. All rates were calculated in five animals/group.

After submitting the data to the Kolmogorov-Smirnov normality test, analysis of variance (two-way ANOVA of repeated measures) was applied to assess performance and body weight between the weeks of study. The Two-Way ANOVA was applied to evaluate the Exercise and Ovary factors and their interactions in the parameters of weight gain, diet consumption, dietary rates and body composition. In the analysis of multiple post hoc comparisons, Tukey's test was used. Pearson's correlation test was used for dietary rates. For statistical analysis, Sigma Stat 3.0 software (Systat Software Inc., USA) was used with a significance level of $p<0.05$.

\section{R E S U L T S}

The Figure 1 shows the blood lactate concentrations. There was no difference in lactate between the rats of the SE and OE groups at the 3 evaluation time points. It was found that blood lactate increased slightly $(p<0.05)$ from the resting condition to 15 and 30 minutes in both workout groups. However, despite 
the lactate elevation between 15 and 30 minutes, this difference was not statistically significant, suggesting stabilization.

There was no difference in the initial body weight of the animals between the groups and between the factors Ovary and Exercise ( $p>0.05$; Table 2 and Figure 2). Regarding the factors Ovary and Exercise, an increase in body weight and weight gain at the end of the experiment was observed. As for the Ovary factor, from the $2^{\text {nd }}$ week onwards, it was found that the animals in the OE group exhibited greater body weight $(p<0.001)$, compared to the SE. The OS group showed greater body weight $(p=0.003)$ than the SE group after the $2^{\text {nd }}$ week, revealing interaction between the exercise and ovary factors.

At the end of the 8th week, an interaction was identified between the factors Ovary and Exercise for final body weight and weight gain, as both OVX and physical inactivity increased body weight and weight gain (Table 2 and Figure 2).

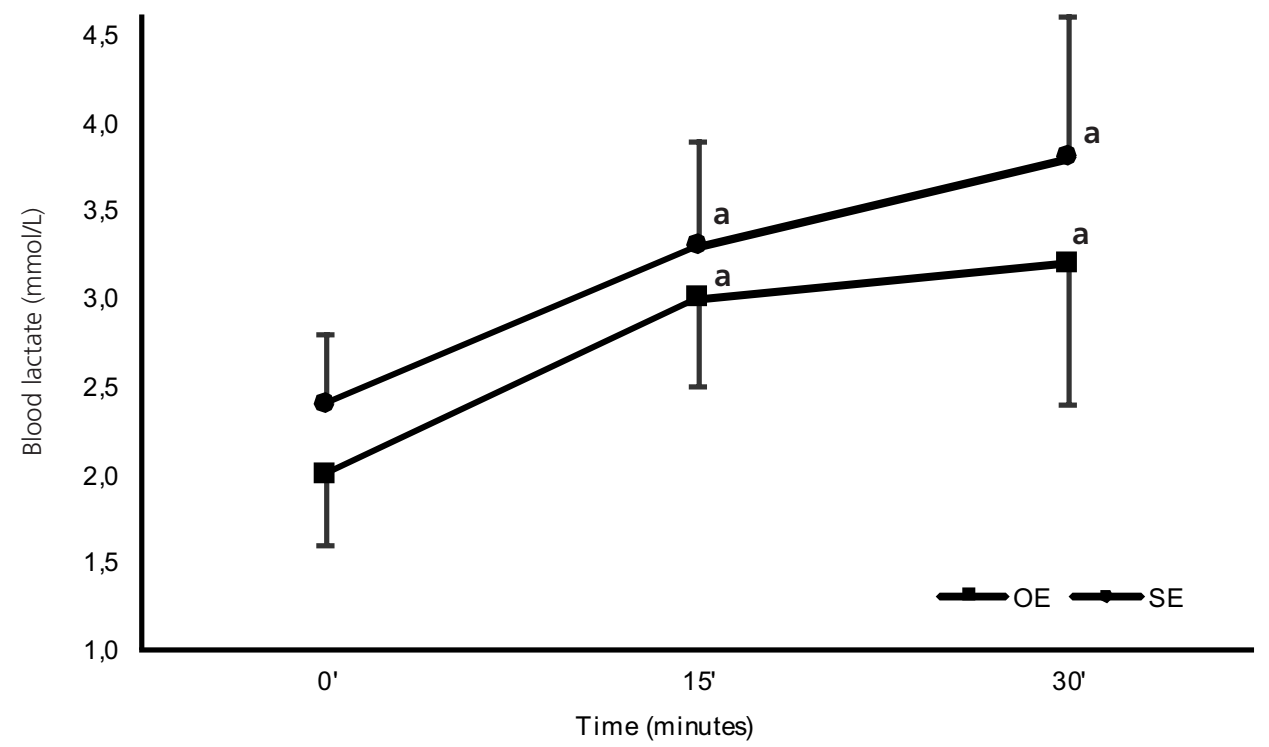

Figure 1 - Blood lactate concentration of the exercised animals (SE and OE groups) in the performance evaluation. Viçosa (MG), Brazil, 2009. Note: Values in mean \pm SD. Significance $(p<0.05)$ : ${ }^{a} V S$. Time 0 minutes for the ANOVA Test Repeated Measures. OE: OVX Exercised; SE: SHAM Exercised.

Table 2 - Initial and final body weight (g), weight gain (g) and dietary intake of the animals. Viçosa (MG), Brazil, 2009.

\begin{tabular}{|c|c|c|c|c|c|c|}
\hline & Initial Weight (g) & Final Weight (g) & Weight Gain (g) & Diet Consumption (g) & FER (\%) & WGR (\%) \\
\hline \multicolumn{7}{|l|}{ Groups } \\
\hline SS & $284.2 \pm 6.7$ & $317.8 \pm 9.0$ & $33.6 \pm 5.7$ & $944.8 \pm 14,5$ & $3.6 \pm 0,6$ & $10.5 \pm 1.6$ \\
\hline SE & $286.1 \pm 7.1$ & $289.9 \pm 7.1$ & $2.9 \pm 2.8^{\mathrm{a}}$ & $908.3 \pm 9,7$ & $0.4 \pm 0,7^{\mathrm{a}}$ & $1.2 \pm 2.1^{\mathrm{a}}$ \\
\hline OS & $290.2 \pm 10.1$ & $350.0 \pm 8.4^{\mathbf{b}}$ & $59.8 \pm 6.2^{\mathrm{ab}}$ & $999.6 \pm 19,0^{a}$ & $6.0 \pm 0,6^{a}$ & $17.1 \pm 1.8^{b}$ \\
\hline $\mathrm{OE}$ & $296.0 \pm 12.0$ & $324.9 \pm 14.2^{\mathbf{b}}$ & $28.9 \pm 3.9^{\mathbf{b c}}$ & $929.8 \pm 21.2^{c}$ & $3.1 \pm 0,4^{b c}$ & $8.8 \pm 1.0^{b c}$ \\
\hline \multicolumn{7}{|c|}{ Exercise Factor } \\
\hline Sedentary & $287.2 \pm 6.5$ & $333.9 \pm 7.1$ & $46.7 \pm 3.5$ & $972.2 \pm 11.8$ & $4.8 \pm 0,4$ & $13.8 \pm 1.2$ \\
\hline Exercised & $291.0 \pm 6.5$ & $307.4 \pm 7.1^{d}$ & $13.5 \pm 3.7^{d}$ & $919.0 \pm 11.8^{d}$ & $1.8 \pm 0,4^{d}$ & $5.0 \pm 1.2^{\mathrm{d}}$ \\
\hline \multicolumn{7}{|l|}{ Ovary Factor } \\
\hline SHAM & $285.1 \pm 6.5$ & $303.9 \pm 7.1$ & $15.9 \pm 3.7$ & $926.5 \pm 11.8$ & $2.0 \pm 0,4$ & $5.8 \pm 1.2$ \\
\hline ovX & $293.1 \pm 6.5$ & $337.5 \pm 7.1^{\mathrm{e}}$ & $44.4 \pm 3.5^{\mathrm{e}}$ & $964.7 \pm 11.8^{\mathrm{e}}$ & $4.5 \pm 0,4^{e}$ & $13.0 \pm 1.2^{\mathbf{e}}$ \\
\hline
\end{tabular}

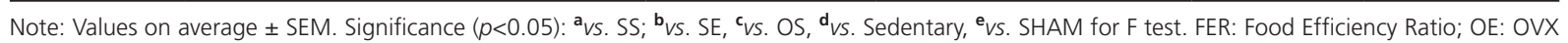
Exercised; OS: OVX Sedentary; SE: SHAM Exercised; SS: SHAM Sedentary; Weight Gain Rate: WGR. 


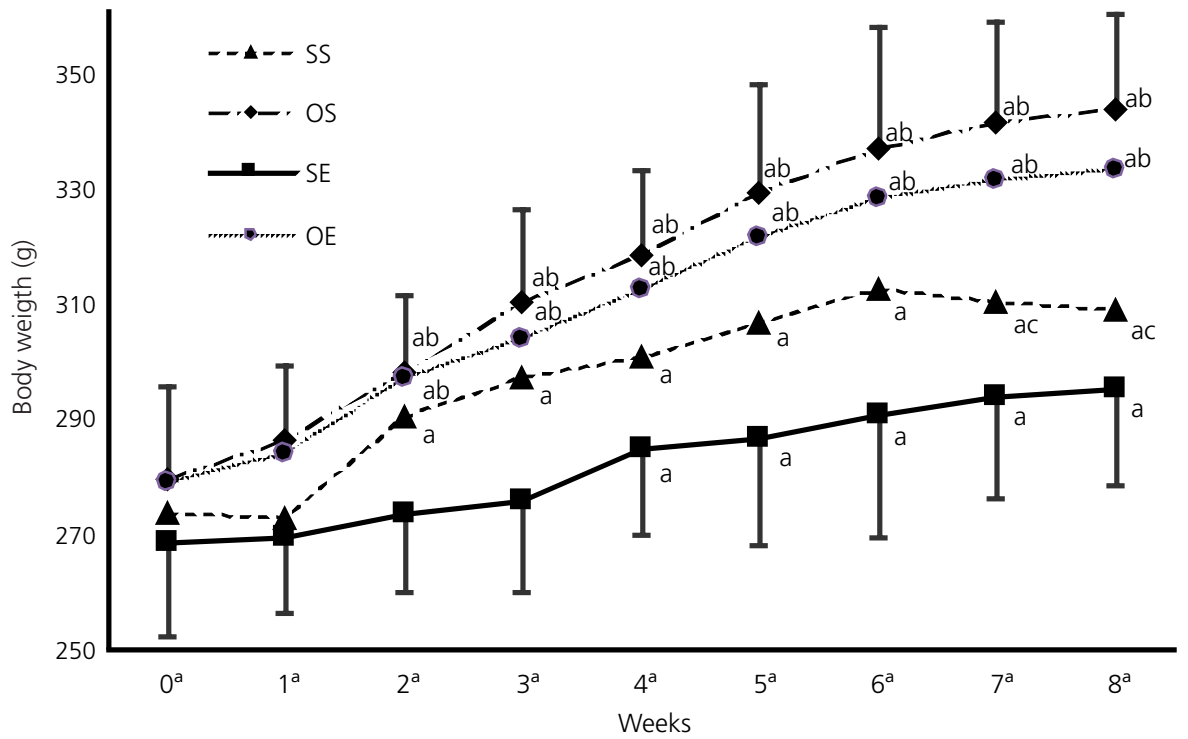

Figure 2 - Body weight of the animals during the experiment. Viçosa (MG), Brazil, 2009.

Note: Significance $(p<0.05)$ : ${ }^{a}$ Vs. $1^{\text {st }}$ week for ANOVA Repeated Measures Test, ${ }^{b_{V S}}$. SE, ${ }^{c}$ VS. OS for Two Way ANOVA Test. OE: OVX Exercised; OS: OVX Sedentary; SE: SHAM Exercised; SS: SHAM Sedentary.

A positive correlation ( $r=0.620$ and $p<0.001)$ was observed between body weight gain and dietary intake throughout the experiment. Thus, the data on weight gain were normalized by dietary intake, and the food efficiency ratio (FER\%) was calculated. OVX and physical inactivity increased body weight gain, dietary intake and FER\% by the end of the experiment (Table 2). An interaction was also identified between factors for dietary intake and FER\%.

In order to exclude the interference of body weight in the weight gain and diet consumption, these parameters were standardized by calculating the weight gain rate (WGR). It was found that the WGR was higher in OVX and physical inactivity, an interaction between factors was observed.

A significant difference was observed in the carcass weight (muscle and bones) between groups and the Ovarian factor (Table 3). In this connection, the data of the fractions of water, protein, ash, fat and carbohydrates in the carcass were standardized by the carcass weight and presented as a percentage. No statistical differences were found for the percentages of ash and carbohydrate $(p>0.05)$. There was an interaction between the factors Ovary and Exercise for the percentage of fat and for visceral fat, in which these parameters were reduced with exercises and increased with OVX.

As for the Ovary factor, it was observed that the carcass weight, the fat and visceral fat rates were higher in the OVX rats than in the Sham rats. However, the OVX rats exhibited a lower percentage of water in the carcass than the Sham rats. Regarding the Exercise factor, it was observed that the rats undergoing workout exhibited higher $\%$ of water and protein content and lower $\%$ of fat and visceral fat content than the sedentary rats (Table 3).

\section{DISCUSSION}

The aim of this study was to assess the impact of low to moderate intensity aerobic exercises and ovariectomy on body composition and food consumption in Wistar rats. The main results were that OVX 
Table 3 - Body Composition in Content and Percentage. Viçosa (MG), Brazil, 2009.

\begin{tabular}{|c|c|c|c|c|c|c|c|}
\hline & Carcass Weight (g) & Water (\%) & Protein (\%) & Ash (\%) & Fat (\%) & $\mathrm{CHO}(\%)$ & Visceral Fat (g) \\
\hline \multicolumn{8}{|l|}{ Groups } \\
\hline SS & $133.3 \pm 3.3$ & $65.8 \pm 0.5$ & $20.3 \pm 0.4$ & $5.6 \pm 0.2$ & $7.8 \pm 0.7$ & $0.5 \pm 0.1$ & $28.7 \pm 2.6$ \\
\hline SE & $132.5 \pm 3.3$ & $67.4 \pm 0.5$ & $20.5 \pm 0.4$ & $5.3 \pm 0.2$ & $6.1 \pm 0.7^{\mathrm{a}}$ & $0.2 \pm 0.1$ & $18.1 \pm 2.6^{a}$ \\
\hline OS & $140.9 \pm 3.3$ & $64.7 \pm 0.5$ & $19.2 \pm 0.4^{a}$ & $5.4 \pm 0.1$ & $10.0 \pm 0.7^{a}$ & $7.0 \pm 0.2$ & $34.9 \pm 2.6^{a}$ \\
\hline OE & $146.9 \pm 3.3^{b}$ & $66.3 \pm 0.5^{c}$ & $20.4 \pm 0.4^{c}$ & $5.2 \pm 0.1$ & $7.9 \pm 0.7^{b c}$ & $0.2 \pm 0.1$ & $27.2 \pm 2.6^{b c}$ \\
\hline \multicolumn{8}{|c|}{ Exercise Factor } \\
\hline Sedentary & $137.1 \pm 2.3$ & $65.3 \pm 0.4$ & $19.7 \pm 0.3$ & $5.5 \pm 0.1$ & $8.9 \pm 0.5$ & $0.5 \pm 0.2$ & $31.8 \pm 1.9$ \\
\hline Exercised & $139.7 \pm 2.3$ & $66.8 \pm 0.4^{d}$ & $20.5 \pm 0.3^{d}$ & $5.3 \pm 0.1$ & $7.0 \pm 0.5^{d}$ & $0.4 \pm 0.1$ & $22.7 \pm 1.9^{d}$ \\
\hline \multicolumn{8}{|l|}{ Ovary Factor } \\
\hline SHAM & $132.9 \pm 2.3$ & $66.6 \pm 0.4$ & $20.4 \pm 0.3$ & $5.5 \pm 0.1$ & $6.9 \pm 0.5$ & $0.6 \pm 0.2$ & $23.4 \pm 1.9$ \\
\hline ovx & $143.9 \pm 2.3^{\mathrm{e}}$ & $65.5 \pm 0.4^{\mathrm{e}}$ & $19.8 \pm 0.3$ & $5.3 \pm 0.1$ & $8.9 \pm 0.5^{e}$ & $0.5 \pm 0.2$ & $31.1 \pm 1.9^{\mathbf{e}}$ \\
\hline
\end{tabular}

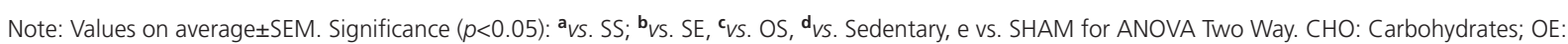
OVX Exercised; OS: OVX Sedentary; SE: SHAM Exercised; SS: SHAM Sedentary.

increased body weight gain, accumulation of visceral fat and the carcass fat rate, in addition to increased food consumption. More importantly, regular low to moderate intensity treadmill workout attenuated these unfavorable ovariectomy effects.

The treadmill aerobic running program used in this study reduced body fat, resulting in lower body weight in the exercised rats. These results are similar to those of Sherk et al. [6], in which 17-week-old Wistar rats running 60 minutes/day at $15 \mathrm{~m} / \mathrm{min}$ for 8 weeks experienced a reduction in fat and body weight. Regular aerobic exercise increases energy expenditure and reduces body fat storage in postmenopausal women and in OVX rats, by increasing the rate of fat oxidation due to the activation of the AMPK enzyme, which regulates lipid metabolism $[10,11,19]$. Another suggested mechanism is that aerobic exercise regulates the use of substrates in the Krebs cycle and electron transport in the respiratory chain], where fatty acids are released from adipocytes through the activation of Hormone-Sensitive Lipase (HSL). This enhances lipolysis and provides energetic substrate to the exercising muscles $[7,9,16,18]$.

Aerobic exercise is considered a strategy to also reduce abdominal and visceral fat $[7,16]$. The results of this study showed that treadmill aerobic running reduced muscle fat in the same proportion as visceral fat. However, there are still questions about the best intensity and duration of exercise that will promote the highest rate of fat oxidation [16]. Ferreira et al. [17] reported that Wistar rats body fat did not change after running exercise on a treadmill at $12 \mathrm{~m} / \mathrm{min}$ for 60 minutes for 10 weeks. Rezaei et al. [14] found that running at $10 \mathrm{~m} / \mathrm{min}$ did not increase free fatty acids and lipolysis-inducing glucocorticoids in Wistar rats; however, this occurred with rates running at $17.5 \mathrm{~m} / \mathrm{min}$. Da Silva Dias et al. [7] observed that OVX rats that ran 60 minutes at $18 \mathrm{~m} / \mathrm{min}$ presented with reduced visceral fat and triglycerides, in addition to an improvement in insulin sensitivity. These findings corroborate the American College of Sports Medicine (ACSM) position, that moderate intensity aerobic exercises are more indicated to prevent weight gain. In our study, moderate intensity aerobic running was used for a shorter time than that of previous studies and lower levels of body fat were observed in OVX rats $[7,10,11,14,19]$. This suggests that exercise of intensity closer to the anaerobic threshold, even for a shorter duration, would promote a higher rate of fat oxidation than very low intensity exercises, showing to be more beneficial in controlling overweight and obesity in individuals with loss of the ovarian function.

One of the benefits of aerobic exercises on body composition seen here was a reduction in body weight. It is believed that this occurred due to the reduction in fat mass as reported in other studies $[14,16,17]$. Despite the De Brito Vieira et al. study [18] suggesting that the ideal speed to obtain benefits 
from running on a treadmill is $17.5 \mathrm{~m} / \mathrm{min}$, the study by Kang et al. [19] demonstrated a reduction in body weight in OVX rats training on $15^{\circ}$ incline treadmill at $16 \mathrm{~m} / \mathrm{min}$ for 60 minutes, for 8 weeks. In the present study we observed a reduction in body weight from the third treadmill training week, without incline, lasting only 30 minutes. This confirms that the aerobic exercise program proposed in this study with a shorter duration than those mentioned above can be useful for obese and postmenopausal individuals, who wish to reduce their body weight.

The results presented here demonstrated that OVX increased body and carcass weight, as well as fat in the carcass and viscera. The increase in total body fat in OVX rats was reported by Sherk et al. [6] in adult rats 8 weeks after surgery and by Tuazon et al. [10] in adult mice 6 weeks after surgery. In addition, Pighon et al. [12] found an increase in subcutaneous, visceral and hepatic fats in female rats 6 weeks after OVX surgery. However, in the present study, in addition to the $32.9 \%$ increase in visceral fat in OVX rats, there was also a $29.0 \%$ increase in the percentage of carcass fat (muscle) thus demonstrating a proportionality in the increase between visceral and muscle fat. This increase in body fat has been reported as being a consequence of aging in postmenopausal women, which could promote insulin resistance and an increased risk of chronic non-communicable diseases $[1,2,4,5,8,11,12,16]$. More importantly, the present study demonstrated that regular aerobic exercise reduced muscle fat in OVX rats to the levels of sedentary Sham rats. This finding confirms that the muscles are sites of fat deposition after loss of the ovarian function, and this fat deposition provides an energy substrate for low to moderate intensity exercises.

The increase in body fat observed in this study may be the main cause for the increase in final body weight and weight gain after OVX. After 3 weeks of post-surgery recovery and 1 more week of experiment, a significant increase in body weight was already observed in OVX rats, compared to Sham rats. These results are similar to those of previous studies $[6,19,25]$. The increase in body weight may be due to hormonal dysfunction and to the greater accumulation of fat as well as to the greater food intake of OVX rats, as observed in the present study $[6,10,12,19]$.

The greater weight gain of OVX and sedentary rats compared to the Sham exercised rats may have been caused by food consumption, which was positively correlated with weight gain, as observed by other authors [6]. However, the results of FER\% and WGR confirm that, regardless of food consumption and body weight, OVX and sedentary rats showed greater weight gain. It is also conceivable that OVX increased physical inactivity by reducing rats spontaneous activity, which can increase food consumption and contribute to weight gain $[7,10]$. Such a situation could be related to aging, sedentary condition and loss of ovarian function [11]. However, our study did not evaluate the spontaneous physical activity of the rats to confirm this mechanism.

As for the proportions of water, fat, protein and ash in the rats carcasses in this study, the values were similar to those of other studies $[17,26]$. However, an unexpected result was that there was no difference in the percentage of ash between the OVX and the Sham rats. The absence of estrogen after OVX should stimulate less vitamin $D$ release, reduce the efficiency of intestinal calcium absorption and promote a negative calcium balance. Consequently, a reduced retention and lower bone calcium levels would be expected $[1,21]$. In addition to the negative calcium balance, OVX can also interfere with the homeostasis of other minerals, such as magnesium, zinc and phosphorus. The results presented here indicate that the magnitude of this mineral reduction in OVX rats was not sufficient to biologically affect individuals with estrogen deficiency.

Finally, the treadmill aerobic workout program used in the present study is characterized as being of low to moderate intensity. This can be confirmed with the blood lactate concentration observed during a training session, as observed by other investigators [14,23]. Blood lactate levels measured at rest increased 
to $3.5 \mathrm{mmol} / \mathrm{L}$ after 15 and 30 minutes running. However, lactate levels did not extrapolate the values of the anaerobic lactate threshold of $4.0 \mathrm{mmol} / \mathrm{L}[14,23]$. According to Rezaei et al. [14], the $16 \mathrm{~m} / \mathrm{min}$ running speed kept lactate below the anaerobic threshold at an intensity of $65 \%$ for Wistar rats, which is associated with the aerobic metabolism and the predominance of fat oxidation as an energy substrate for workout. These findings are of clinical relevance, as they indicate regular aerobic workout as an important strategy to control overweight and obesity in individuals deprived of the ovarian function, which is a common physical activity among postmenopausal women.

The present study has limitations. First, the rats spontaneous activity during the period they were housed in the cages was not measured; thus it is not possible to correlate it with weight gain and food consumption. Second, the mineral content in bones to determine the impact of OVX and aerobic workout on their storage levels has not been evaluated, which indicates that new studies with a longer intervention time should be performed to investigate this topic.

\section{CONCLUSION}

It was concluded that ovariectomy and physical inactivity increase obesogenic indicators and regular low to moderate intensity aerobic workout attenuates these unfavorable effects in rats.

\section{CONTRIBUTORS}

FSC FRANCO participated in the conception, design, execution, writing and revision of the study. NMB COSTA contributed to the conception, design, execution, writing and revision of the study. AJ NATALI contributed to the conception, design, writing and revision of the study.

\section{REFERENCIAS}

1. Kapus $\mathrm{O}$, Gaba A, Lehnert M. Relationships between bone mineral density, body composition, and isokinetic strength in postmenopausal women. Bone Rep. 2020;12:100255. https://doi.org/10.1016/j.bonr.2020.100255

2. Morardpour F, Koushkie Jahromi M, Fooladchang M, Rezaei R, Sayar Khorasani MR. Association between physical activity, cardiorespiratory fitness, and body composition with menopausal symptoms in early postmenopausal women. Menopause. 2020;27(2):230-7. https://doi.org/10.1097/GME.0000000000001441

3. Omiyale W, Allen NE, Sweetland S. Body size, body composition and endometrial cancer risk among postmenopausal women in UK Biobank. Int J Cancer. 2020;27. https://doi.org/ 10.1002/ijc.33023

4. Perez-Gomez J, Adsuar JC, Garcia-Gordillo MA, Munoz P, Romo L, Maynar M, et al. Twelve weeks of whole body vibration training improve regucalcin, body composition and physical fitness in postmenopausal women: a pilot study. Int J Environ Res Public Health. 2020;17(11). https://doi.org/10.3390/ijerph17113940

5. Boldarine VT, Pedroso AP, Brandao-Teles C, Lo Turco EG, Nascimento CMO, Oyama LM, et al. Ovariectomy modifies lipid metabolism of retroperitoneal white fat in rats: a proteomic approach. Am J Physiol Endocrinol Metab. 2020;319(2):e427-e37. https://doi.org/10.1152/ajpendo.00094.2020

6. Sherk VD, Jackman MR, Higgins JA, Giles ED, Foright RM, Presby DM, et al. Impact of exercise and activity on weight regain and musculoskeletal health post-ovariectomy. Med Sci Sports Exerc. 2019;51(12):2465-73. https:// doi.org/10.1249/MSS.0000000000002082

7. Dias DS, Silva ICM, Bernardes N, Monzani JOB, Stoyell-Conti FF, Machi JF, et al. Exercise training initiated at old stage of lifespan attenuates aging-and ovariectomy-induced cardiac and renal oxidative stress: role of baroreflex. Exp Gerontol. 2019;124:110635. https://doi.org/10.1016/j.exger.2019.110635

8. Tin Tin S, Reeves GK, Key TJ. Body size and composition, physical activity and sedentary time in relation to endogenous hormones in premenopausal and postmenopausal women: findings from the UK biobank. Int J Cancer. 2020;14. https://doi.org/10.1002/ijc.33010 
9. Pereira RM, Muñoz VR, Anaruma CP, Gaspar RC, Gaspar RS, Ropelle ER, et al. Long-term effects of moderate physical exercise during early childhood on insulin sensitivity in rats during adulthood. Rev Bras Educ Fís Esporte. 2020;34(2):227-36. https://doi.org/10.11606/1807-5509202000020227

10. Tuazon MA, Campbell SC, Klein DJ, Shapses SA, Anacker KR, Anthony TG, et al. Effects of ovariectomy and exercise training intensity on energy substrate and hepatic lipid metabolism, and spontaneous physical activity in mice. Metabolism. 2018;83:234-44. https://doi.org/10.1016/j.metabol.2018.02.011

11. Dupuit M, Rance M, Morel C, Bouillon P, Pereira B, Bonnet A, et al. Moderate-intensity continuous training or high-intensity interval training with or without resistance training for altering body composition in postmenopausal women. Med Sci Sports Exerc. 2020;52(3):736-45. https://doi.org/10.1249/MSS.0000000000002162

12. Pighon A, Barsalani R, Yasari S, Prud'homme D, Lavoie JM. Does exercise training prior to ovariectomy protect against liver and adipocyte fat accumulation in rats? Climacteric. 2010;13(3):238-48. https://doi. org/10.3109/13697130903009203

13. Miyatake K, Muneta T, Ojima M, Yamada J, Matsukura Y, Abula K, et al. Coordinate and synergistic effects of extensive treadmill exercise and ovariectomy on articular cartilage degeneration. Bmc Musculoskelet Disord. 2016;17:238. https://doi.org/10.1186/s12891-016-1094-8

14. Rezaei S, Agha-Alinejad H, Molanouri Shamsi M, Jafari M, Voltarelli FA, Naderi A, et al. Evaluation of efforts in untrained Wistar rats following exercise on forced running wheel at maximal lactate steady state. J Exerc Nutrition Biochem. 2017;21(1):26-32. https://doi.org/10.20463/jenb.2017.0040

15. Oliveira EC, Santos RC, Becker LK, Coelho DB, Pedrosa ML, Silva ME. Physical exercise improves body weight gain and liver function in malnourished rats without disturbing the redox balance. Rev Nutr. 2018;31(5):443-53. https:// doi.org/10.1590/1678-98652018000500002

16. Nascimento OV, Boleti APA, Schwertz M, Lima ES. Dietary supplementation with camu-camu and continuous exercises in the treatment of obesity. Rev Nutr. 2018;31(1):25-33. https://doi.org/10.1590/1678-98652018000100003

17. Ferreira LG, Bergamaschi CT, Lazaretti-Castro M, Heilberg IP. Effects of creatine supplementation on body composition and renal function in rats. Med Sci Sports Exerc. 2005;37(9):1525-9. https://doi.org/10.1249/01. mss.0000177555.94271.44

18. Vieira WHB, Ferraresi C, Schwantes MLB, Perez SEA, Baldissera V, Cerqueira MS, et al. Photobiomodulation increases mitochondrial citrate synthase activity in rats submitted to aerobic training. Lasers Med Sci. 2017;21(3):1-10. https:// doi.org/10.1007/s10103-017-2424-2

19. Kang YS, Kim CH, Kim JS. The effects of downhill and uphill exercise training on osteogenesis-related factors in ovariectomy-induced bone loss. J Exerc Nutrition Biochem. 2017;30;21(3):1-10. https://doi.org/10.20463/ jenb.2017.0010

20. Furlanetto Junior R, Martins FM, Oliveira AA, Nunes PR, Michelin MA, Murta EF, et al. Loss of ovarian function results in increased loss of skeletal muscle in arthritic rats. Rev Bras Ginecol Obstet. 2016;38(2):56-64. https://doi. org/10.1055/s-0035-1571265

21. Silva ST, Costa NMB, Franco FSC, Natali AJ. Calcium and caffeine interaction in increased calcium balance in ovariectomized rats. Rev Nutr. 2013;26(3):313-22.

22. Cao Z, Zhang T, Xu C, Jia Y, Wang T, Zhu B. AlN-93 diet as an alternative model to lieber-decarli diet for alcoholic cardiomyopathy. Alcohol Clin Exp Res. 2019;43(7):1452-61. https://doi.org/10.1111/acer.14069

23. Rahmati M, Kazemi A. Various exercise intensities differentially regulate GAP-43 and CAP-1 expression in the rat hippocampus. Gene. 2019;692:185-94. https://doi.org/10.1016/j.gene.2019.01.013

24. Azhar A, Akmal M, Hambal M, Sabri M, Rosa TS. Effects of polymorphism of myostatin and fatty acid-binding protein 4 genes on the chemical composition of meat in cull female Aceh cattle. Vet World. 2020;13(7):1334-43. https://doi.org/10.14202/vetworld.2020.1334-1343

25. Vidal R, Volkweis G, Ywazaki JL, Randi MAF, Loureiro APC, Gomes ARS. The effects of stretching on muscle morphometry of ovariectomized rats. Fisioter Mov. 2020;33:e003312. https://doi.org/10.1590/1980-5918.033.A012

26. Franco FSC, Natali AJ, Costa NMB, Lunz W, Gomes GJ, Carneiro Junior MA, et al. Effects of creatine supplementation and power training on performance and lean body mass of rats. Rev Bras Med Esporte. 2007;13(5):268e-73e. https://doi.org/10.1590/S1517-86922007000500004 